Article

\title{
Ordered ZnO/Ni Hollow Microsphere Arrays as Anode Materials for Lithium Ion Batteries
}

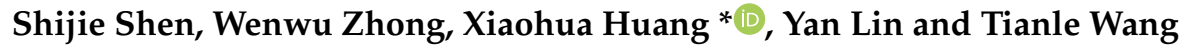 \\ Department of Materials Engineering, Taizhou University, Taizhou 318000, China; shensj@tzc.edu.cn (S.S.); \\ tianmenwenwu@163.com (W.Z.); linyan@tzc.edu.cn (Y.L.); wt10203@tzc.edu.cn (T.W.) \\ * Correspondence: huangxh@tzc.edu.cn
}

Received: 27 March 2019; Accepted: 10 April 2019; Published: 11 April 2019

\begin{abstract}
Well-designed nanostructures are very important for the electrochemical performance of lithium-ion electrode materials. In order to improve the electrochemical performance of $\mathrm{ZnO}$-based anode materials, $\mathrm{ZnO} / \mathrm{Ni}$ composite film, assembled by ordered hollow microsphere arrays, is designed and fabricated by means of magnetron sputtering technique using a colloidal crystal template composed of a monolayer of ordered polystyrene (PS) microspheres. The ordered hollow microsphere structure as well as the constituent $\mathrm{Ni}$ component of the $\mathrm{ZnO} / \mathrm{Ni}$ film show major advantages of homogenizing electrode reactions, enhancing electrode reaction kinetics and accommodating volume change of active materials, so they can reduce electrode polarization and stabilize electrode structure. Consequently, the resulting ordered $\mathrm{ZnO} / \mathrm{Ni}$ hollow microspheres arrays deliver an initial charge capacity of $685 \mathrm{mAh} \mathrm{g}^{-1}$, an initial coulombic efficiency of $68 \%$, and a capacity retention rate of $69 \%$ after 100 cycles, all of which are higher than those of the pure $\mathrm{ZnO}$ film. These results show progress in developing more stable $\mathrm{ZnO}$-based anode materials for lithium ion batteries.
\end{abstract}

Keywords: Zinc oxide; hollow microsphere; nanocomposite; anode materials; lithium ion battery

\section{Introduction}

Transition-metal oxides are important materials for energy storage and conversion [1,2]. Zinc oxide, as a typical transition-metal oxide, is a promising anode material for lithium-ion batteries due to its high theoretical capacity of $988 \mathrm{mAh} \mathrm{g}^{-1}$ that is $\sim 2.7$ times that of traditional graphite [3,4]. However, the research on $\mathrm{ZnO}$-based anode materials is far less than other transition-metal oxides due to its much poorer actual electrochemical performance. For example, $\mathrm{ZnO}$ often experiences dramatic capacity decrease, even to meaningless values, just in the early stages of the cycling process. Designing nanostructures and forming composites are common ways to overcome this problem and they are often used in combination. Over the past decade, plenty of $\mathrm{ZnO}$-based composites have been prepared by introducing metals and/or carbon [5-7], and meanwhile, they have been designed as various nanostructures, for example, porous [8,9], hollow [10], spherical [11], core/shell [12], and yolk/shell [13].

Unlike other transition-metal oxides, the reduction product of $\mathrm{ZnO}$ by $\mathrm{Li}$, i.e., metallic $\mathrm{Zn}$, is still electrochemically active towards lithium. Therefore, theoretically, the lithium-storage mechanism of $\mathrm{ZnO}$ includes two steps, which are, the conversion reaction $\left(\mathrm{ZnO}+2 \mathrm{Li} \rightleftharpoons \mathrm{Zn}+\mathrm{Li}_{2} \mathrm{O}\right)$ as well as the alloying/dealloying reaction $(\mathrm{Zn}+\mathrm{Li} \rightleftharpoons \mathrm{LiZn})[3,4]$. However, these two reactions are usually partially reversible, and meanwhile, they both cause large electrode volume changes, which are responsible for the extremely poor electrochemical performance of $\mathrm{ZnO}$ anode materials. Therefore, rational designing the component and structure of electrode materials to increase the utilization rate and accommodate the volume change at the same time is an important approach to achieve enhanced electrochemical performance. 
Herein, an unconventional $\mathrm{ZnO} / \mathrm{Ni}$ composite electrode with a nanostructure of ordered hollow microsphere arrays is designed and fabricated. It is expected that the ordered $\mathrm{ZnO} / \mathrm{Ni}$ hollow microsphere arrays have better abilities of homogenizing electrode reactions, enhancing electrode reaction kinetics and accommodating electrode volume change.

\section{Materials and Methods}

\subsection{Sample Preparation}

Ordered $\mathrm{ZnO} / \mathrm{Ni}$ hollow microsphere arrays were prepared by magnetron sputtering using a colloidal crystal template composed of a monolayer of ordered polystyrene (PS) microspheres. Commercial dispersion of PS microspheres with a diameter of $1 \mu \mathrm{m}$ was diluted by a mixture of ethanol and distilled water to obtain a monolayer of ordered PS microspheres at the liquid/gas interface. The monolayer was picked up by a polished stainless-steel plate and transferred to its surface. The deposition of $\mathrm{ZnO}$ and $\mathrm{Ni}$ on the PS template was proceeded by magnetron sputtering (DE500, DE Technology, Beijing, China). ZnO and Ni targets were fixed at $20 \mathrm{~cm}$ above the substrate holder. After the chamber was pumped to a base pressure of $0.5 \mu \mathrm{Torr}$, high purity argon (99.999\%) was introduced as working gas and the pressure was maintained at $8 \mathrm{mTorr}$. $\mathrm{ZnO}$ was deposited first for $1000 \mathrm{~s}$ under radio-frequency power of $50 \mathrm{~W}$, and then $\mathrm{Ni}$ was deposited for $500 \mathrm{~s}$ under direct-current power of $50 \mathrm{~W}$. The resulting sample was finally annealed at $300{ }^{\circ} \mathrm{C}$ for $2 \mathrm{~h}$ in vacuum to remove the PS template. For comparison, pure $\mathrm{ZnO}$ film was prepared by radio-frequency magnetron sputtering under $50 \mathrm{~W}$ for $10 \mathrm{~h}$ on a bare stainless-steel substrate.

\subsection{Materials Characterizations}

Ordered $\mathrm{ZnO} / \mathrm{Ni}$ hollow microsphere arrays were characterized by means of scanning electron microscopy (SEM, S-4800, Hitachi, Tokyo, Japan) and transmission electron microscopy (TEM, Tecnai G2 F20, FEI, Hillsboro, OR, USA). The mass of the components in the film was weighed by a high-precision balance in a simultaneous thermal analyzer (STA 449 F3, Netzsch, Selb, Germany).

\subsection{Electrochemical Measurements}

CR2025 cells were used for electrochemical tests, which were assembled in an argon-filled glove box using the film as working electrode and lithium foil as counter electrode. The electrolyte was $1 \mathrm{M}$ $\mathrm{LiPF}_{6}$ dissolved in a mixture of ethylene carbonate (EC) and dimethyl carbonate (DMC) with a volume ratio of 1:1.

Galvanostatic discharge-charge tests of cells were performed on a battery test system (CT2001A, LAND, Wuhan, China) using different current densities from 0.1 to $2.0 \mathrm{~A} \mathrm{~g}^{-1}$ in the voltage range of $0.02-3 \mathrm{~V}$. Cyclic voltammetry $(\mathrm{CV})$ tests were carried out on an electrochemical workstation (PGSTAT302N, Autolab, Utrecht, The Netherlands) at a scan rate of $0.1 \mathrm{mV} \mathrm{s}^{-1}$ between 0 and $3 \mathrm{~V}$.

\section{Results and Discussion}

SEM images of $\mathrm{ZnO} / \mathrm{Ni}$ film are shown in Figure 1. The film is composed of microspheres with almost the same diameter (Figure 1a). These microspheres are close-packed and periodically assembled as a single-layer ordered structure. The magnified image of a single microsphere indicates a diameter of about $1 \mu \mathrm{m}$. The cross-sectional image (Figure 1b) of the electrode confirms the monolayer structure of the PS microsphere stacking. It is known from a cracked microsphere that it has a hollow structure.

TEM results of the microspheres are presented in Figure 2. The low-magnification image (Figure 2a) shows typical morphology of hollow spheres. Selected area electron diffraction (SAED) pattern displays two sets of diffraction rings that can be assigned to $\mathrm{ZnO}$ and $\mathrm{Ni}$, respectively, indicative of the polycrystalline nature of each component. The image of a single hollow microsphere (Figure 2b) 
shows that it is assembled by ultrafine nanoparticles. EDS mapping of $\mathrm{Zn}, \mathrm{O}$ and $\mathrm{Ni}$ elements indicates that both $\mathrm{ZnO}$ and $\mathrm{Ni}$ are distributed uniformly.
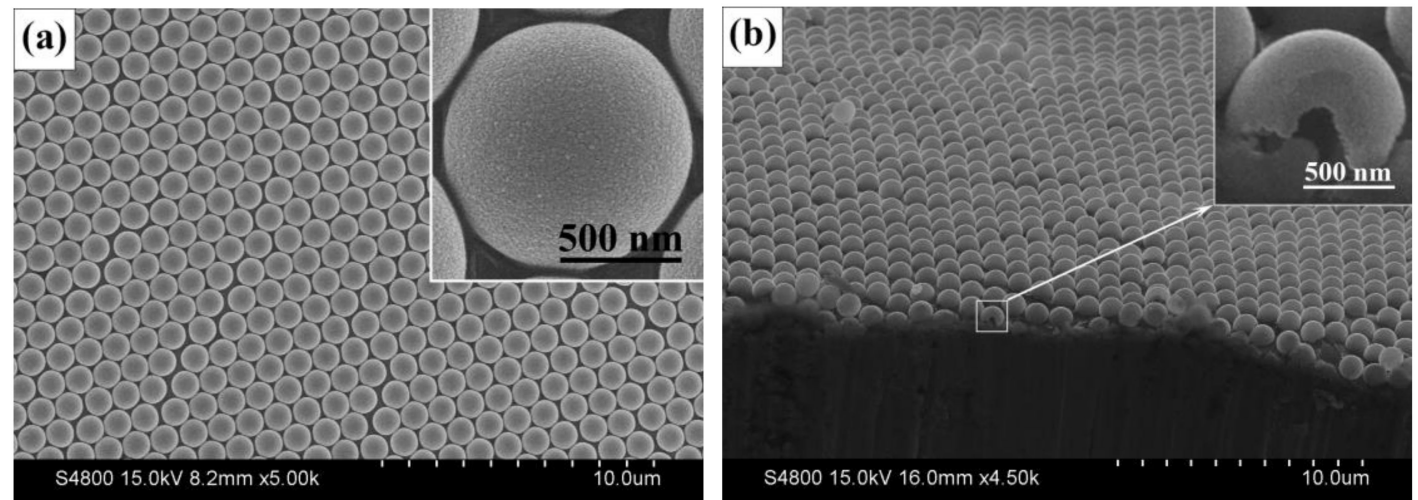

Figure 1. SEM images of ordered $\mathrm{ZnO} / \mathrm{Ni}$ hollow microsphere arrays, (a) top-view image and (b) cross-sectional image.
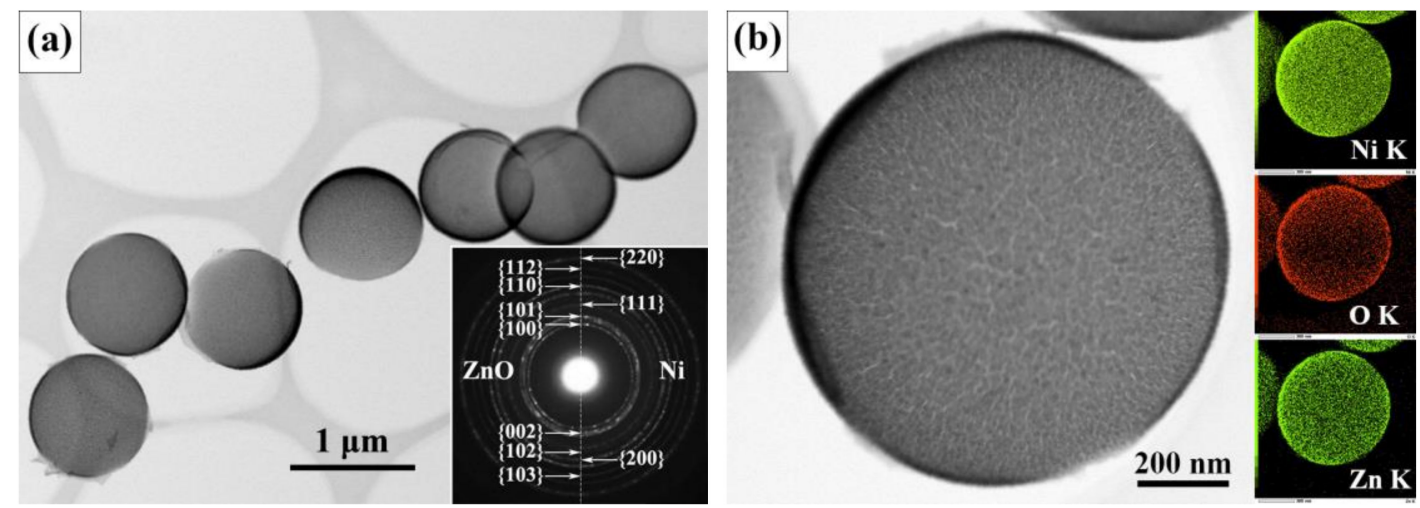

Figure 2. TEM results of $\mathrm{ZnO} / \mathrm{Ni}$ hollow microspheres, (a) the low-magnification image and the corresponding SAED pattern, $(\mathbf{b})$ the image of a single microsphere and the corresponding EDS mapping of $\mathrm{Zn}, \mathrm{O}$, and Ni elements.

According to the weight increments of the film, it can be determined that the average areal densities of $\mathrm{ZnO}$ and $\mathrm{Ni}$ components in the $\mathrm{ZnO} / \mathrm{Ni}$ composite film are $\sim 65$ and $\sim 40 \mu \mathrm{g} \mathrm{cm}{ }^{-2}$, respectively.

The electrochemical performances of ordered $\mathrm{ZnO} / \mathrm{Ni}$ hollow microsphere arrays and pure $\mathrm{ZnO}$ film are compared under the same test conditions. $C V$ curves tested at $0.1 \mathrm{mV} \mathrm{s}^{-1}$ are presented in Figure 3. Both two curves show only one cathodic peak at $\sim 0.3 \mathrm{~V}$ with high intensity in the first scan, which is the common feature of all transition-metal oxides. This peak is related to the electrochemical reactions between $\mathrm{ZnO}$ and $\mathrm{Li}$ including the conversion reaction of $\mathrm{ZnO}$ to $\mathrm{Zn}$ and the further alloying reaction of $\mathrm{Zn}$ to LiZn, as well as other side reactions such as the formation of solid electrolyte interface (SEI) layer [14,15]. Apart from the first cathodic scan, the curves are quite similar in shape. The cathodic peak at $\sim 0.4 \mathrm{~V}$ is related to the alloying reaction of $\mathrm{Zn}$ with $\mathrm{Li}$. The first four low-potential anodic peaks below $0.7 \mathrm{~V}$ ascribe to the multi-step dealloying process of LiZn $[16,17]$. The last anodic peak at $\sim 2.5 \mathrm{~V}$ corresponds to the conversion reaction of $\mathrm{Zn}$ back to $\mathrm{ZnO}[4,14,16]$. The other pair of cathodic and anodic peaks, near 0.8 and $1.3 \mathrm{~V}$, respectively, correspond to the partially reversible formation/decomposition of a 'polymer/gel-like layer' that is generated from side reactions occurring at the interface [2,18]. However, it is obvious that the $\mathrm{CV}$ curves of $\mathrm{ZnO}$ electrode show two differences compared with those of $\mathrm{ZnO} / \mathrm{Ni}$ electrode. Firstly, its $2.5 \mathrm{~V}$ anodic peak appears only in the first cycle, which implies that the conversion reaction mechanism, i.e., $\mathrm{Zn}+\mathrm{Li}_{2} \mathrm{O} \rightarrow \mathrm{ZnO}+2 \mathrm{Li}$, does not exist in the subsequent cycles, and this undoubtedly reduces the utilization of the active material and thus affects the reversible capacity. Secondly, the pair of peaks at 0.8 and $1.3 \mathrm{~V}$, show higher but rapidly 
decreased intensities in the cycling process, which indicates that the 'polymer/gel-like layer' is quite electrochemically unstable in the early cycles.
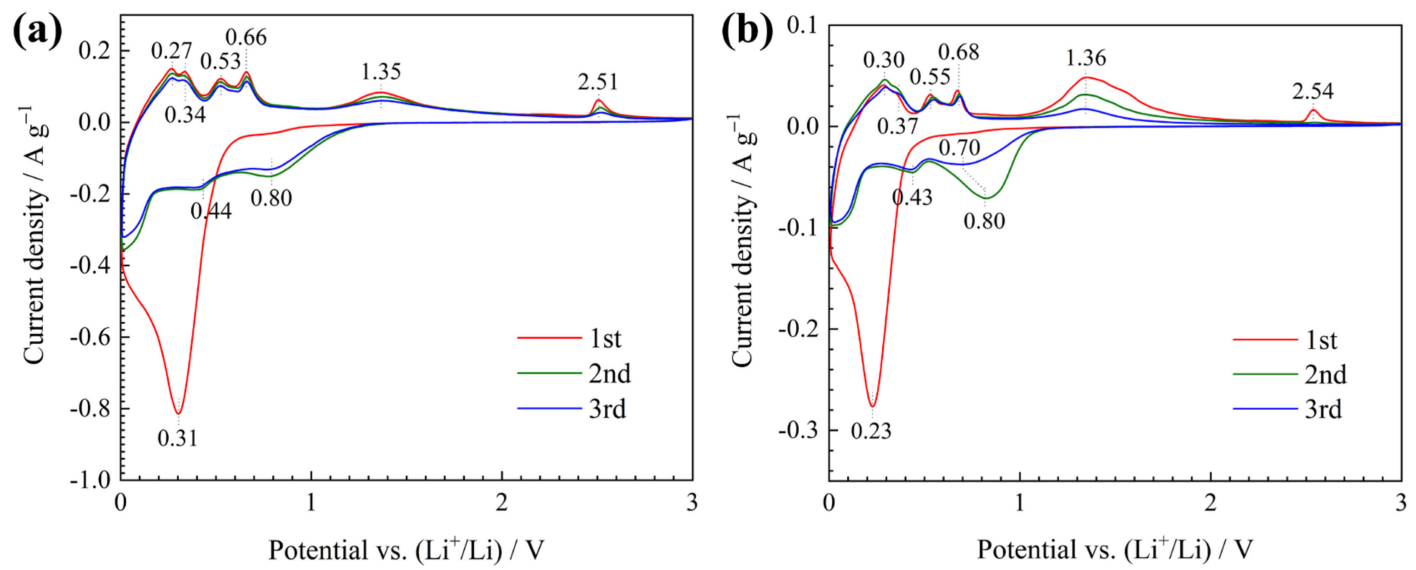

Figure 3. Cyclic voltammetry (CV) curves of (a) $\mathrm{ZnO} / \mathrm{Ni}$ and (b) $\mathrm{ZnO}$ electrodes.

Galvanostatic discharge-charge curves of the two electrodes tested at $0.1 \mathrm{~A} \mathrm{~g}^{-1}$ are compared in Figure 4. The potential of plateaus or slopes are almost consistent with those of the peaks in CV curves. For $\mathrm{ZnO} / \mathrm{Ni}$ electrode (Figure 4a), it delivers an initial reversible capacity (charge capacity) of $685 \mathrm{mAh} \mathrm{g}^{-1}$ and an initial coulombic efficiency of $68 \%$. For $\mathrm{ZnO}$ electrode (Figure $4 \mathrm{~b}$ ), these values are lower, only $660 \mathrm{mAh} \mathrm{g}^{-1}$ and $63 \%$, respectively.
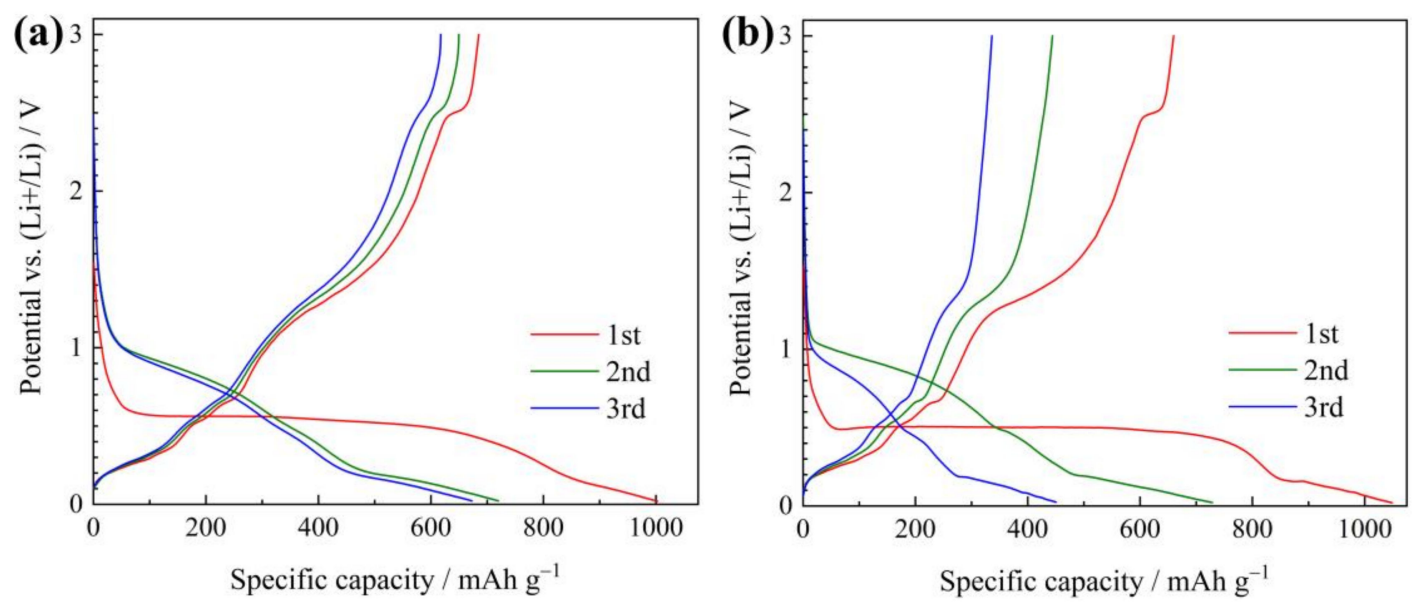

Figure 4. Galvanostatic discharge-charge curves of (a) $\mathrm{ZnO} / \mathrm{Ni}$ and (b) $\mathrm{ZnO}$ electrodes.

Cycling performances of the two electrodes tested at $0.1 \mathrm{~A} \mathrm{~g}^{-1}$ are shown in Figure $5 . \mathrm{ZnO} / \mathrm{Ni}$ electrode exhibits much higher capacities during the cycling process, as shown in Figure $5 \mathrm{a}$, and its charge capacity after 100 cycles is $470 \mathrm{mAh} \mathrm{g}^{-1}, 69 \%$ of its initial value. In contrast, $\mathrm{ZnO}$ electrode fades very fast to the value below $100 \mathrm{mAh} \mathrm{g}^{-1}$ just after only 30 cycles, and the final capacity is as low as $60 \mathrm{mAh} \mathrm{g}^{-1}$. Figure $5 \mathrm{~b}$ compares their coulombic efficiency in the early period. The higher coulombic efficiency of $\mathrm{ZnO} / \mathrm{Ni}$ electrode indicates better reversibility of electrode reactions.

For the evaluation of rate capability, the above-mentioned $\mathrm{ZnO} / \mathrm{Ni}$ electrode, which has been cycled for 100 times at $0.1 \mathrm{~A} \mathrm{~g}^{-1}$, continues to be tested at different current densities of $0.2,0.5,1.0$, 2.0, and $0.1 \mathrm{~A} \mathrm{~g}^{-1}$ in turn, for 10 cycles at each stage, and the results are presented in Figure 6. It is obvious that the electrode still has some capacity of about $105 \mathrm{mAh} \mathrm{g}^{-1}$ at the highest current density of $2.0 \mathrm{~A} \mathrm{~g} \mathrm{~g}^{-1}$, and finally, when the current density returns to the initial $0.1 \mathrm{~A} \mathrm{~g}^{-1}$, the capacities can rise back to about $405 \mathrm{mAh} \mathrm{g}^{-1}$. 

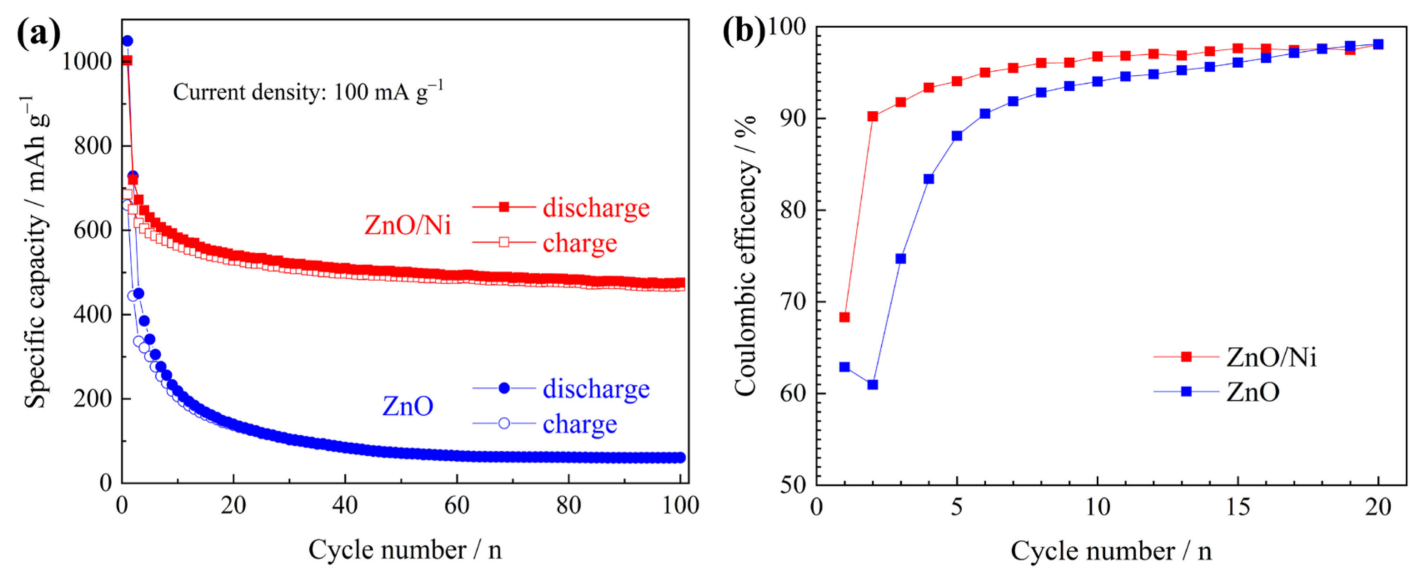

Figure 5. The evolution of (a) capacity and (b) coulombic efficiency during the cycling process of the two electrodes.

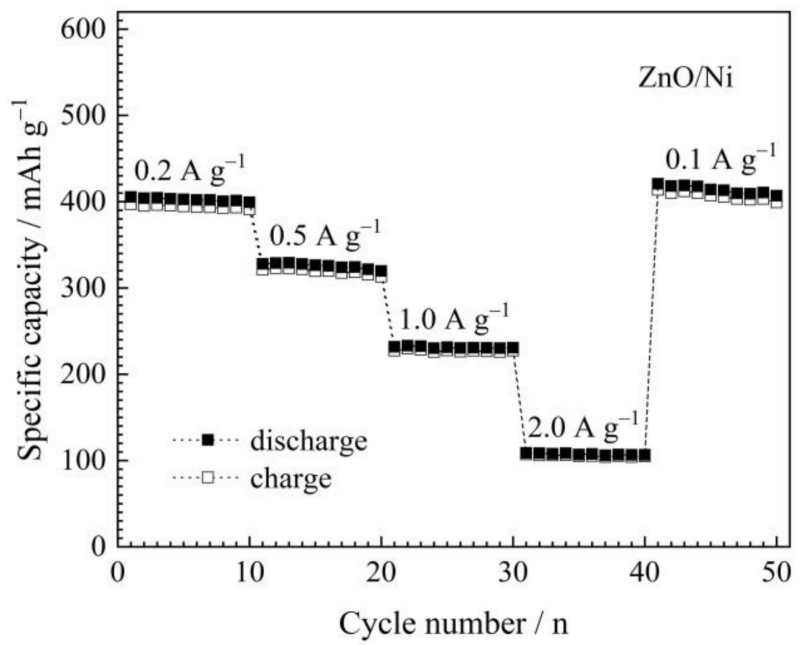

Figure 6. Rate capability of $\mathrm{ZnO} / \mathrm{Ni}$ electrode tested at different current densities.

Figure 7 compares the SEM images of the two electrodes after cycling. Both two electrodes are covered by the 'polymer/gel-like layers', which show some shrinkage under the long-time irradiation of electron beam. For $\mathrm{ZnO} / \mathrm{Ni}$ electrode, the film is still continuously and evenly distributed, but for $\mathrm{ZnO}$ electrode, large cracks or even gullies can be observed clearly. Obviously, it can be concluded that the $\mathrm{ZnO} / \mathrm{Ni}$ electrode has much better structure stability. The ordered hollow microsphere arrays are capable of uniformly absorbing the volume change of electrode materials, which is very advantageous for minimizing the internal stress and thus stabilizing the electrode structure. Conversely, for pure $\mathrm{ZnO}$ electrode, because of the lack of accommodation space for volume changes, the film fractures inevitably under the high stress. This not only causes active materials to peel off the electrode, resulting in fast capacity fading, but also creates new materials/electrolyte interfaces and forms new 'polymer/gel-like layers', resulting in decreased coulombic efficiency.

The nanostructure of ordered hollow microsphere arrays is also capable of reducing electrode polarization. Firstly, ordered-array arrangement ensures uniform distribution of active materials, which makes the electrochemical reactions proceed more homogeneously and completely, and this is beneficial to maximize the utilization of active materials. Secondly, the hollow microspheres offer a porous structure, which can enlarge reaction interface, reduce local current density and shorten charge transfer distance. In addition, the Ni component in the composite can also increase the electric conductivity. All these advantages are quite helpful to enhance the kinetics of electrode reaction, which is the key factor for the reversible capacity and rate capability. 

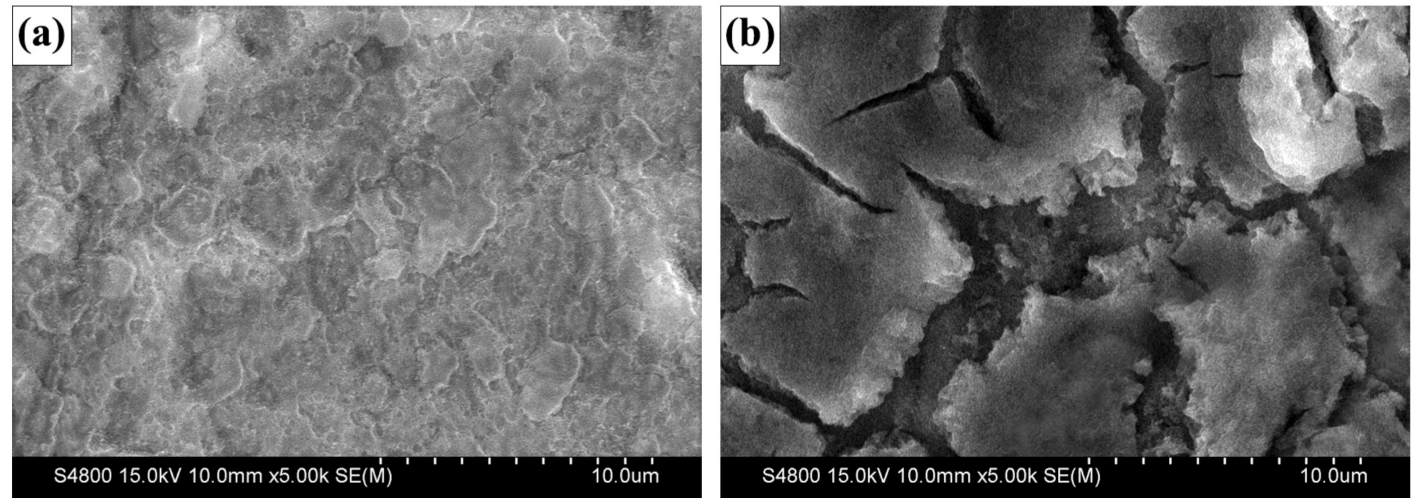

Figure 7. SEM images of (a) $\mathrm{ZnO} / \mathrm{Ni}$ and (b) $\mathrm{ZnO}$ electrodes after 20 cycles.

\section{Conclusions}

In summary, ordered $\mathrm{ZnO} / \mathrm{Ni}$ hollow microsphere arrays are successfully prepared by magnetron sputtering technique using a monolayer of polystyrene microspheres as the colloidal crystal template. These hollow microspheres have a diameter of $1 \mu \mathrm{m}$, and they are close-packed into an ordered-array structure. As anode materials for lithium-ion batteries, $\mathrm{ZnO} / \mathrm{Ni}$ electrode delivers significantly enhanced electrochemical performance including reversible capacity, coulombic efficiency, and cycling stability as compared to pure $\mathrm{ZnO}$ electrode. The improvements are attributed to the ordered hollow microsphere array structure and the $\mathrm{Ni}$ component of the $\mathrm{ZnO} / \mathrm{Ni}$ electrode, as they show great advantages of reducing electrode polarization and stabilizing electrode structure.

Author Contributions: Conceptualization, X.H.; Formal analysis, Y.L.; Investigation, S.S. and W.Z.; Project administration, X.H.; Supervision, X.H.; Validation, T.W.; Writing—original draft, S.S. and X.H.

Funding: This research was funded by National Natural Science Foundation of China (grant number 51802211) and Zhejiang Provincial Natural Science Foundation of China (grant number LQ15E010001).

Conflicts of Interest: The authors declare no conflict of interest.

\section{References}

1. Poizot, P.; Laruelle, S.; Grugeon, S.; Dupont, L.; Tarascon, J.M. Nano-sized transition-metal oxides as negative-electrode materials for lithium-ion batteries. Nature 2000, 407, 496-499. [CrossRef] [PubMed]

2. Poizot, P.; Laruelle, S.; Grugeon, S.; Tarascon, J.M. Rationalization of the low-potential reactivity of 3d-metal-based inorganic compounds toward Li. J. Electrochem. Soc. 2002, 149, A1212-A1217. [CrossRef]

3. Belliard, F.; Irvine, J.T.S. Electrochemical performance of ball-milled $\mathrm{ZnO}-\mathrm{SnO}_{2}$ systems as anodes in lithium-ion battery. J. Power Sources 2001, 97-98, 219-222. [CrossRef]

4. Fu, Z.W.; Huang, F.; Zhang, Y.; Chu, Y.; Qin, Q.Z. The electrochemical reaction of zinc oxide thin films with lithium. J. Electrochem. Soc. 2003, 150, A714-A720. [CrossRef]

5. Huang, X.H.; Wu, J.B.; Lin, Y.; Guo, R.Q.; Zhong, W.W. Ag decorated hierarchical structured ZnO microspheres and their enhanced electrochemical performance for lithium ion batteries. Int. J. Electrochem. Sci. 2014, 9, $6707-6716$.

6. Yuan, G.; Xiang, J.; Jin, H.; Wu, L.; Jin, Y.; Zhao, Y. Anchoring ZnO nanoparticles in nitrogen-doped graphene sheets as a high-performance anode material for lithium-ion batteries. Materials 2018, 11, 96. [CrossRef] [PubMed]

7. Li, H.; Liu, Z.; Yang, S.; Zhao, Y.; Feng, Y.; Bakenov, Z.; Zhang, C.; Yin, F. Facile synthesis of ZnO nanoparticles on nitrogen-doped carbon nanotubes as high-performance anode material for lithium-ion batteries. Materials 2017, 10, 1102. [CrossRef] [PubMed]

8. Huang, X.H.; Guo, R.Q.; Wu, J.B.; Zhang, P. Mesoporous ZnO nanosheets for lithium ion batteries. Mater. Lett. 2014, 122, 82-85. [CrossRef]

9. Cai, D.; Zhang, H.; Wang, T. MOF-derived porous $\mathrm{ZnO} / \mathrm{ZnFe}_{2} \mathrm{O}_{4}$ hybrid nanostructures as advanced anode materials for lithium ion batteries. Mater. Lett. 2017, 197, 241-244. [CrossRef] 
10. Zhang, Y.; Lu, Y.; Feng, S.; Liu, D.; Ma, Z.; Wang, S. On-site evolution of ultrafine ZnO nanoparticles from hollow metal-organic frameworks for advanced lithium ion battery anodes. J. Mater. Chem. A 2017, 5, 22512-22518. [CrossRef]

11. Xie, Q.; Liu, P.; Zeng, D.; Xu, W.; Wang, L.; Zhu, Z.Z.; Mai, L.; Peng, D.L. Dual electrostatic assembly of graphene encapsulated nanosheet-assembled $\mathrm{ZnO}-\mathrm{Mn}-\mathrm{C}$ hollow microspheres as a lithium ion battery anode. Adv. Funct. Mater. 2018, 28, 1707433. [CrossRef]

12. Fang, J.; Yuan, Y.F.; Wang, L.K.; Ni, H.L.; Zhu, H.L.; Gui, J.S.; Yang, J.L.; Chen, Y.B.; Guo, S.Y. Hierarchical $\mathrm{ZnO@NiO} \mathrm{core-shell} \mathrm{nanorod} \mathrm{array} \mathrm{as} \mathrm{high} \mathrm{performance} \mathrm{anode} \mathrm{material} \mathrm{for} \mathrm{lithium-ion} \mathrm{batteries.} \mathrm{Mater.} \mathrm{Lett.}$ 2013, 111, 1-4. [CrossRef]

13. Xie, Q.; Zhang, X.; Wu, X.; Wu, H.; Liu, X.; Yue, G.; Yang, Y.; Peng, D.L. Yolk-shell ZnO-C microspheres with enhanced electrochemical performance as anode material for lithium ion batteries. Electrochim. Acta 2014, 125, 659-665. [CrossRef]

14. Huang, X.H.; Xia, X.H.; Yuan, Y.F.; Zhou, F. Porous ZnO nanosheets grown on copper substrates as anodes for lithium ion batteries. Electrochim. Acta 2011, 56, 4960-4965. [CrossRef]

15. Pelliccione, C.J.; Ding, Y.; Timofeeva, E.V.; Segre, C.U. In situ XAFS study of the capacity fading mechanisms in $\mathrm{ZnO}$ anodes for lithium-ion batteries. J. Electrochem. Soc. 2015, 162, A1935-A1939. [CrossRef]

16. Zhang, C.Q.; Tu, J.P.; Yuan, Y.F.; Huang, X.H.; Chen, X.T.; Mao, F. Electrochemical performances of Ni-coated $\mathrm{ZnO}$ as an anode material for lithium-ion batteries. J. Electrochem. Soc. 2007, 154, A65-A69. [CrossRef]

17. Kim, C.; Kim, J.W.; Kim, H.; Kim, D.H.; Choi, C.; Jung, Y.S.; Park, J. Graphene oxide assisted synthesis of self-assembled zinc oxide for lithium-ion battery anode. Chem. Mater. 2016, 28, 8498-8503. [CrossRef]

18. Laruelle, S.; Grugeon, S.; Poizot, P.; Dolle, M.; Dupont, L.; Tarascon, J.M. On the origin of the extra electrochemical capacity displayed by MO/Li cells at low potential. J. Electrochem. Soc. 2002, 149, A627-A634. [CrossRef]

(C) 2019 by the authors. Licensee MDPI, Basel, Switzerland. This article is an open access article distributed under the terms and conditions of the Creative Commons Attribution (CC BY) license (http://creativecommons.org/licenses/by/4.0/). 